\title{
Antioxidant and Antimicrobial Activities of Naturally Occurring Flavonoids from M. heterophylla and the Safety Evaluation in Wistar Rats
}

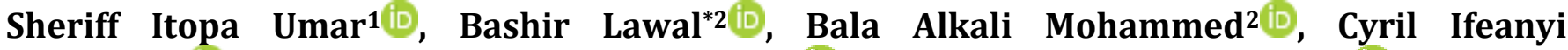 Obiekezie $^{2}$, Abdulsalam Hassan Adewuyi ${ }^{2}$, Shukurat Bisola Babalola ${ }^{3}$, Stephen Damaola Ariyeloye 4}

${ }^{1}$ MTech of Biochemistry, Federal Polytechnic, Ile-Oluji, Ondo State, Nigeria.

${ }^{2}$ Department of Biochemistry, Federal University of Technology, Minna, Nigeria.

${ }^{3}$ Department of Chemistry, Federal University of Technology, Minna, Nigeria.

${ }^{4}$ Department of Biochemistry, Federal University of Technology, Akure, Nigeria.

\begin{tabular}{ll}
\hline Article Info & A B S T R A C T \\
\hline $\begin{array}{l}\text { Article Type: } \\
\text { Research }\end{array}$ & Background: \\
\hline Article History: & Maytenus heterophylla (M. heterophylla) is commonly used in African \\
Received: 04.08 .2019 & traditional medicine for the management of various ailments. The present \\
Accepted: 13.10 .2019 & study evaluated the antioxidant, antimicrobial and safety properties of the \\
& Flavonoid extract of $M$. heterophylla in Wister rats.
\end{tabular}

Methods:

* Corresponding Author:

Bashir Lawal

Department of Biochemistry, Federal

University of Technology, Minna,

Nigeria.

E-mail: bashirlawal12@gmail.com
The Flavonoid was subjected to antibacterial study via agar well diffusion method, and antioxidant study using 2, 2'-diphenyl-1-picrylhydrazyl (DPPH) and ferric reducing antioxidant properties (FRAP) assays. Subacute toxicity were carried out by the oral administration of the extract at a daily dose of 50 or $100 \mathrm{mg} / \mathrm{kg}$ for 28 days.

Results:

The extract produced significant antioxidants activities with $\mathrm{IC}_{50}$ of $33.07 \pm 0.84 \mu \mathrm{g} / \mathrm{mL} \& 38.08 \pm 0.89 \mu \mathrm{g} / \mathrm{mL}$ in DPPH and FRAPS models respectively. It produced a dose-dependent inhibition of $S$. aureus, E.coli, $P$. aeruginosa, K. pneumonia and S. Typhi with MIC between $12.5 \mu \mathrm{g} / \mathrm{mL}$ to $25 \mu \mathrm{g} / \mathrm{mL}$. The flavonoid was safe on acute exposure to rats $\left(\mathrm{LD}_{50}>5000\right.$ $\mathrm{mg} / \mathrm{kg})$. However, the chronic exposure significantly $(\mathrm{p}<0.05)$ decreased the creatinine, bilirubin concentrations and increased aspartate transaminase (AST) activities while the total protein, albumin, alanine transaminase (ALT), alkaline phosphatise (ALP), urea, chloride, potassium and sodium concentrations were comparable with those in the controls. The organs-body weights ratios also compared well with the controls $(\mathrm{p}<0.05)$.

Conclusions:

The findings showed that the Flavonoid extract of $M$. heterophylla was relatively non-toxic following acute or chronic exposures at 50-100 $\mathrm{mg} / \mathrm{kg}$. The flavonoid extract may potentially serve as a candidate agent for the development of an anti-microbial drug and to enhance the antioxidant capacity in rats.

Keywords:

Antibacterial; Anti-Oxidants; Flavonoids; Maytenus Heterophylla; Toxicity

How to cite this paper:

Umar SI, Lawal B, Mohammed BA, Obiekezie CI, Adewuyi AH, Babalola SB, Ariyeloye SD. Antioxidant and Antimicrobial Activities of Naturally Occurring Flavonoids from M. heterophylla and the Safety Evaluation in Wistar Rats. Iran J Toxicol. 2019;13(4):39-44

\section{INTRODUCTION}

Infectious diseases due to bacteria are serious health concerns worldwide (1). Of the annual death rate of 52 million, over 17 million of them are attributed to infectious diseases, including about 9 million deaths in young children (2). The rise in bacterial resistance to conventional antimicrobials is a major healthcare problem in the management of infectious diseases ( $\underline{3})$.

The implicative role of free radicals in many pathological conditions, such as liver disease, diabetes, inflammation, coronary heart diseases, carcinogenesis, 
drug toxicity and neurodegenerative disorders like Alzheimer and Parkinson diseases has been well established $(\underline{4,5})$. Redox reaction in bodily systems can lead to the generation of free radicals, which initiate chain reactions that cause cellular damages. However, antioxidants cease the reaction chain by removing the intermediates radicals and preventing further oxidation reactions ( $\underline{5})$. The development of resistance as well as side effects and toxicity associated with conventional antioxidant and antimicrobial drugs call for an alternative safe and cost-effective therapy ( $\underline{6})$.

Natural products particularly from medicinal plants have demonstrated their significance as sources of metabolites with therapeutic virtues, and are considered as reliable candidates for the discovery of novel phyto-pharmaceuticals with various biological activities, such as anti-parasitic, antimicrobial and antioxidant effects $(\underline{5,7-9})$. The high interest in natural antimicrobials and antioxidants in safeguarding the human body from oxidative stressors and infectious diseases is increasing around the globe due to their efficacy, less side effects and high safety as opposed to those for synthetics drugs $(\underline{10})$. Thus, natural products are the main spotlight of researchers for the isolation of antimicrobial and antioxidant derivatives that can modulate metabolic pathways and promote health and well-being in humans (1ㅡ).

Maytenus heterophylla (M. heterophylla) is an African shrubs commonly known as spike thorns, and is a medicinal plants commonly used by the traditional healers to treat respiratory disorders, snake bites, wounds and dysentery (12). Previous studies have established that plasmodial, leishmanial $(13,14)$, inflammatory $(\underline{15})$ and bacterial $(\underline{16})$ conditions can be treated with $M$. heterophylla. Also, phytochemical studies have identified flavonoids, alkaloid, terpenoid and triterpenes in the leaf extract of $M$. heterophylla (17). The toxicity profiling of such an important plant is very helpful to appraise the safety; however, there have been no reports on the antioxidant and antimicrobial activities of the flavonoid fraction of this plant in the literature. The aim of this study was to isolate flavonoids from the leaf extract and to investigate the antioxidant and antimicrobial effects and to explore its safety in rats.

\section{MATERIALS AND METHODS}

Samples of the fresh leaves of $M$. Heterophylla were obtained from Niger State and identified by Botanist at the Department of Biological science Federal University of Technology, Minna, Nigeria. Healthy albino rats were procured from animals holding units of School of Life Sciences, Federal University of Technology, Minna, Nigeria. They were allowed unrestricted access to rat food and water. Ascorbic acid (Merck Co.; Germany), 1,1-diphenyl-2-picrylhydrazyl radical (DPPH) (SigmaAldrich Co.; USA). All biochemical assay kits were either obtained from Randox Laboratories Ltd, United Kingdom or Agape Diagnostics, Switzerland. All other chemicals were of analytical grade.
Isolation of Flavonoids: The leave samples were washed and dried for 2 weeks at $37^{\circ} \mathrm{C}$, and ground using a grinder mill. A $50 \mathrm{~g}$ of the plant material was extracted with $200 \mathrm{~mL}$ of methanol, using soxhlet apparatus and the resulting extract was concentrated in a rotary evaporator. The methanol extract was dissolved in distilled water and extracted with nbutanol mixed with distilled water. The butanol extract was subjected to column chromatography on silica gel, eluted with n-hexane and methanol yielding $7.6 \mathrm{~g}$ of a crude flavonoids mixture according to the method described by Jouad et al. (18).

Antibacterial Assay: The following bacteria: Pseudomonas aeuruginisa, Salmonella typhi, Klebsiella pneumonia, Staphylococcus aureus and Escherichia coli were the species used for the experiments. Organisms were isolated by standard methods, maintained on agar plates and refrigerated until further use. The antibacterial activity of the extract was carried out using agar-well diffusion method as described by Tsado

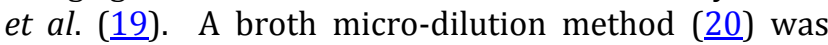
used to determine the minimum inhibitory concentration (MIC) and minimum bactericidal concentration (MBC) of the extract in triplicates.

Antioxidant study: At varying concentrations (2.5$100 \mu \mathrm{g} / \mathrm{mL}$ ) of the flavonoid, using ascorbic acid as the reference drug, the radical scavenging activity was measured by2, 2'-diphenyl-1- picrylhydrazyl (DPPH) assay (21). Fe3+ ion reducing power of the flavonoid was evaluated as described by Oyaizu (22).

Toxicological Study: The acute toxicity of the flavonoid was evaluated as described by the Organization for Economic Co-operation and Development (OECD, 2001). The chronic toxicity of the flavonoid fraction was tested according to the method described by Shittu et al. (르). Briefly, a total of 15 rats were randomly divided into three groups of five rats each. Group 1 rats were orally given normal saline (10 $\mathrm{mL} / \mathrm{kg}$ ) to serve as the control. Groups 2 and 3 received $50 \mathrm{mg} / \mathrm{kg}$ and $100 \mathrm{mg} / \mathrm{kg}$ flavonoid fraction of $M$. heterophylla, respectively, for 28 days. On the $29^{\text {th }}$ day, animals were denied food for $12 \mathrm{~h}$ and were sacrificed using diethyl ether anaesthesia. Blood samples were collected, centrifuged and the sera were prepared for biochemical analyses (24). The organs including; liver, kidney, heart, spleen and intestine were collected, washed and weighed. The relative organ weights were determined using the following formula:

Organs/body weight: The absolute organ weight (g) rat body weight on scarifies day $(\mathrm{g})$

Biochemical Parameters: The activities or concentrations of aspartate transaminase (AST), alanine transaminase (ALT), alkaline phosphatase (ALP), total proteins, albumin, bilirubin, urea, potassium, creatinine, sodium, and chloride in the sera of the rats were determined by standard methods (2529) on a spectrophotometer.

Data Analysis: Data generated were analyzed using statistical package for social science (SPSS). Differences between groups were compared by analysis of variance 
(ANOVA) followed by Duncan's Multiple Range Test. The significance level was considered $\mathrm{P}<0.05$.

Ethical Approval: The principles governing the use of laboratory animals as laid out by the Federal University of Technology, Minna Committee on Ethics for Medical and Scientific Research and also existing internationally accepted principles for laboratory animal use and care as contained in the Canadian Council on Animal Care Guidelines and Protocol Review were duly observed.

\section{RESULTS}

Antioxidants Activities: Flavonoid fraction of $M$. heterophylla produced progressive inhibition of DPPH radicals with increasing concentrations. The $\mathrm{IC}_{50}$ recorded were $33.07 \pm 0.84 \mu \mathrm{g} / \mathrm{mL} \& 36.44 \pm 1.78 \mu \mathrm{g} / \mathrm{mL}$ for the flavonoid fraction and ascorbic acid, respectively (Table 1). The ability to transform $\mathrm{Fe}^{3+}$ to $\mathrm{Fe}^{2+}$ as illustrated in Table 2 reflected the $\mathrm{IC}_{50}$ value of $38.08 \pm 0.89 \mu \mathrm{g} / \mathrm{mL}$ and $24.39 \pm 0.46 \mu \mathrm{g} / \mathrm{mL}$ for the flavonoid fraction and ascorbic acid, respectively.

Table 1. DPPH radical scavenging activities of flavonoid fraction of $M$.

\begin{tabular}{lll}
\multicolumn{3}{c}{ Heterophylla. } \\
\cline { 1 - 2 } Conc. $(\mu \mathrm{g} / \mathrm{mL})$ & Flavonoid extract & Ascorbic Acid \\
\hline 5 & $19.35 \pm 0.45$ & $18.56 \pm 1.64$ \\
10 & $29.35 \pm 0.45$ & $42.73 \pm 3.45$ \\
20 & $47.43 \pm 0.56$ & $55.89 \pm 3.21$ \\
40 & $69.34 \pm 0.32$ & $69.34 \pm 4.34$ \\
80 & $81.56 \pm 0.25$ & $77.94 \pm 2.34$ \\
100 & $93.56 \pm 0.34$ & $85.34 \pm 4.32$ \\
IC $_{\mathbf{5 0}}$ & $\mathbf{3 3 . 0 7} \pm 0.84$ & $\mathbf{3 6 . 4 4} \pm \mathbf{1 . 7 8}$ \\
\hline \multicolumn{2}{l}{ Values are mean \pm SEM of 3 determinations. }
\end{tabular}

Table 2. FRAP activity of leaf extracts of flavonoid Fraction of M. Heterophylla.

\begin{tabular}{ccc}
\hline Conc. $\boldsymbol{\mu g} / \mathbf{m L}$ & Flavonoid & A. Acid \\
\hline 100 & $77.45 \pm 0.94$ & $93.95 \pm 1.05$ \\
80 & $65.43 \pm 0.11$ & $84.08 \pm 1.67$ \\
40 & $52.35 \pm 0.32$ & $78.40 \pm 0.533$ \\
20 & $45.67 \pm 0.18$ & $60.56 \pm 0.59$ \\
10 & $32.13 \pm 0.94$ & $43.03 \pm 0.75$ \\
50 & $21.56 \pm 0.38$ & $29.79 \pm 0.84$ \\
2.5 & $9.56 \pm 0.29$ & $18.68 \pm 0.92$ \\
IC & $\mathbf{3 8 . 0 8} \pm 0.89$ & $\mathbf{2 4 . 3 9 \pm 0 . 4 6}$ \\
\hline Values are mean \pm SEM of 3 determinations.
\end{tabular}

Table 3. Susceptibility of the test organisms to the flavonoid fraction of M. heterophylla.

\begin{tabular}{lccccc}
\hline & \multicolumn{5}{c}{ Zone of Inhibition (mm) } \\
\hline M. heterophylla & S. aureus & E. coli & $\begin{array}{c}\text { P. } \\
\text { aeruginosa }\end{array}$ & $\begin{array}{c}\text { K. } \\
\text { pneumoniae }\end{array}$ & S.typhi \\
\hline $25 \mu \mathrm{g} / \mathrm{mL}$ & $17.87 \pm 0.30$ & $17.98 \pm 0.94$ & $18.23 \pm 0.22$ & $15.97 \pm 0.98$ & $10.34 \pm 0.34$ \\
$50 \mu \mathrm{g} / \mathrm{mL}$ & $17.90 \pm 0.53$ & $18.05 \pm 0.77$ & $18.96 \pm 0.45$ & $18.95 \pm 0.83$ & $12.67 \pm 1.05$ \\
$75 \mu \mathrm{g} / \mathrm{mL}$ & $19.89 \pm 0.98$ & $22.54 \pm 1.98$ & $21.08 \pm 1.09$ & $21.56 \pm 0.98$ & $15.83 \pm 0.86$ \\
$100 \mu \mathrm{g} / \mathrm{mL}$ & $21.06 \pm 0.32$ & $24.98 \pm 1.89$ & $23.87 \pm 0.93$ & $25.76 \pm 0.85$ & $20.34 \pm 1.23$ \\
Ampicloxbechem* & $39.09 \pm 1.97$ & $36.96 \pm 1.93$ & $26.98 \pm 0.87$ & $36.89 \pm 1.07$ & $39.45 \pm 0.79$ \\
\hline
\end{tabular}

Values are Mean \pm SEM of triplicate determinations. Values with the same superscript alphabets are not significantly different $(P \leq 0.05) . *=30 \mu \mathrm{g} / \mathrm{mL}$

Table 4. The minimum inhibitory (MIC) and bactericidal (MBC) concentrations of the flavonoid fraction of $M$. Heterophylla.

\begin{tabular}{lcc}
\hline Test organism & MIC $\boldsymbol{\mu g} / \mathbf{m L}$ & MBC $\boldsymbol{\mu g} / \mathbf{m L}$ \\
\hline P. aeuruginisa & 12.5 & 50 \\
Klebsiella pneumoniae & 12.5 & 100 \\
Salmonella typhi & 25 & 100 \\
Staphylococcus aureus & 12.5 & 50 \\
Escherichia coli & 12.5 & 50 \\
\hline
\end{tabular}


Table 5. Effects of flavonoid fraction of M. heterophylla on serum biochemical parameters in rats.

\begin{tabular}{lccc}
\hline & \multicolumn{3}{c}{ Extract (Mg/kg bw) } \\
\cline { 2 - 4 } Biochemical Parameter & $\mathbf{5 0}$ & $\mathbf{1 0 0}$ & Control \\
\hline Protein (mg/dl) & $37.89 \pm 2.96^{\mathrm{a}}$ & $38.82 \pm 4.03^{\mathrm{a}}$ & $37.57 \pm 2.78^{\mathrm{a}}$ \\
Bilirubin (mg/dl) & $3.02 \pm 0.32^{\mathrm{a}}$ & $2.71 \pm 0.22^{\mathrm{a}}$ & $5.32 \pm 0.46^{\mathrm{b}}$ \\
Albumin (mg/dl) & $3.04 \pm 0.78^{\mathrm{a}}$ & $3.26 \pm 0.56^{\mathrm{a}}$ & $3.43 \pm 0.36^{\mathrm{a}}$ \\
ALT(U/L) & $4.98 \pm 1.45^{\mathrm{a}}$ & $5.44 \pm 2.34^{\mathrm{a}}$ & $5.45 \pm 0.24^{\mathrm{a}}$ \\
AST(U/L) & $43.45 \pm 4.32^{\mathrm{b}}$ & $34.56 \pm 4.32^{\mathrm{ab}}$ & $28.30 \pm 2.35^{\mathrm{a}}$ \\
ALP (U/L) & $138.97 \pm 12.38^{\mathrm{a}}$ & $132.41 \pm 7.13^{\mathrm{a}}$ & $141.35 \pm 3.56^{\mathrm{a}}$ \\
Creatinine & $8.45 \pm 1.34^{\mathrm{a}}$ & $10.73 \pm 0.96^{\mathrm{ab}}$ & $11.34 \pm 0.45^{\mathrm{b}}$ \\
Urea & $27.05 \pm 3.56^{\mathrm{a}}$ & $29.63 \pm 3.75^{\mathrm{a}}$ & $26.78 \pm 2.46^{\mathrm{a}}$ \\
Chloride & $216.78 \pm 3.45^{\mathrm{a}}$ & $234.56 \pm 3.57^{\mathrm{a}}$ & $222.57 \pm 4.56^{\mathrm{a}}$ \\
Potassium & $6.23 \pm 0.29^{\mathrm{a}}$ & $6.32 \pm 0.39^{\mathrm{a}}$ & $6.20 \pm 0.88^{\mathrm{a}}$ \\
Sodium & $24.45 \pm 3.45^{\mathrm{a}}$ & $25.08 \pm 2.34^{\mathrm{a}}$ & $22.67 \pm 2.45^{\mathrm{a}}$ \\
\hline
\end{tabular}

Values are mean \pm SEM of 5 determinations. Values along the same row with different superscripts are significantly different $(\mathrm{p}<0.05)$.

Table 6. Relative organ weight ratio of rats administered flavonoid fraction of M. Heterophylla.

\begin{tabular}{lllllll}
\hline ROUPS & Liver & Heart & Intestine & Lungs & Kidney & Spleen \\
\hline 50 & $2.34 \pm 0.19^{\mathrm{a}}$ & $0.89 \pm 0.00^{\mathrm{a}}$ & $3.56 \pm 0.03^{\mathrm{a}}$ & $1.56 \pm 0.00^{\mathrm{a}}$ & $0.87 \pm 0.02^{\mathrm{a}}$ & $0.44 \pm 0.00^{\mathrm{a}}$ \\
100 & $2.05 \pm 0.09^{\mathrm{a}}$ & $0.77 \pm 0.00^{\mathrm{a}}$ & $3.06 \pm 0.03^{\mathrm{a}}$ & $1.23 \pm 0.00^{\mathrm{a}}$ & $0.89 \pm 0.00^{\mathrm{a}}$ & $0.42 \pm 0.05^{\mathrm{a}}$ \\
Control & $2.38 \pm 0.56^{\mathrm{a}}$ & $0.84 \pm 0.00^{\mathrm{a}}$ & $3.45 \pm 0.01^{\mathrm{a}}$ & $1.59 \pm 0.00^{\mathrm{a}}$ & $0.79 \pm 0.00^{\mathrm{a}}$ & $0.45 \pm 0.01^{\mathrm{a}}$ \\
\hline
\end{tabular}

Values are mean \pm SEM of 5 determinations. Values along the same column with different

superscripts are significantly different $(\mathrm{p}<0.05)$.

\section{DISCUSSION}

Generally, natural products particularly from plant extracts have been reported for their pharmacological properties ( $\underline{5})$. It was reported that crude extract of $M$. heterophylla exhibited significant antioxidant and antimicrobial properties (16). Moreover, previous phytochemical studies on M. Heterophylla revealed the presence of different classes of secondary metabolites particularly phenols and flavonoids, which have been implicated in the pharmacological activities of the plant extract $(\underline{30,31})$.

The results of antioxidant activity showed that the flavonoid fraction of $M$. heterophylla had DPPH and FRAP radical scavenging activities in a dose-dependent manner (Tables 1 and 2). Our results are in line with that of a previous study (19) that reported that the antioxidant potentials of Newbouldia laevis and Crateva adansonii leaf extracts increased as the concentration increased. The activities recorded for the flavonoid ( $\left.\mathrm{IC}_{50}=33.07 \pm 0.84 \mu \mathrm{g} / \mathrm{mL}\right)$ was higher than that of ascorbic acid $(33.07 \pm 0.84 \mu \mathrm{g} / \mathrm{mL})$. Also, the activities of the flavonoid were significantly better than the scavenging properties reported for some medicinal plants, such as Padina pavonica $\left(\mathrm{IC}_{50}=5.59 \mathrm{mg} / \mathrm{ml}\right.$ ), Laurenica majuscule $\left(\mathrm{IC}_{50}=14.3 \mathrm{mg} / \mathrm{ml}\right)$, and Laurencia catarinensis $\left(\mathrm{IC}_{50}=53.8 \mathrm{mg} / \mathrm{ml}\right)(\underline{32})$. These potent scavenging activities could be very useful in the management of certain neurodegenerative disorders, AIDS and cancers $(\underline{5,6})$.

Antimicrobial activity is one of the important properties of flavonoid compounds. The results of the MICs revealed that both the gram positive and gramnegative bacteria tested were susceptible to the flavonoid fraction of $M$. heterophylla. The MIC values ranged from $12.5 \mu \mathrm{g} / \mathrm{mL}$ to $25 \mu \mathrm{g} / \mathrm{mL}$ for both grampositive and gram-negative bacteria except for $S$. typhi $(25 \mu \mathrm{g} / \mathrm{mL})$. The inhibition of bacterial strains $(S$. Aureus \& E. coli) suggests that the flavonoid possesses broad spectrum antibacterial properties, which could be used in the treatment of skin diseases and food poisoning, in which these pathogens are often implicated (19). They inhibit the hydrolytic enzymes (proteases), microbial adhesion, and cell envelope transport proteins (ㅁ). In addition, flavonoids form complexes with soluble and extra cellular proteins of bacterial cell walls leading to their death ( $\underline{33})$.

The need for the analysis of biochemical parameters following subacute administration of plant extracts has been suggested by previous studies $(\underline{23,24,34})$, which have revealed that some alterations in serum concentrations of biochemical parameters, such as AST, ALT, ALP, total proteins and bilirubin are the indicators of hepatocellular damage, compromised cell membrane integrity, hepatitis, cirrhosis, and bile duct obstruction (흐). Similarly, the concentration of serum electrolytes, urea, and creatinine reflect the secretory and excretory roles of kidney (34). Consequently, alterations in the serum concentrations of creatinine, bilirubin and AST observed in this study suggest that the normal function of the rats' kidneys and liver had been hampered (23). Such alteration could, negatively affect the metabolic activities of the liver and consequently the health of the animals. The significant alterations in the serum creatinine concentrations could reflect the flavonoid ability to interfere with its metabolism (24).

Interestingly, the 28-day administration of flavonoid fraction to rats did not cause any significant alterations to the levels of serum total protein, albumin, ALT, ALP, Urea, chloride, potassium and sodium compared with the control values. This simply implies that the functional integrity of liver and kidney cells had not been compromised. Similarly, since ALT is more specific to liver than AST, the insignificant decrease in serum ALT seen in flavonoid treated groups suggests that the extract does not have hepatotoxic effects (르). Moreover, it is worth mentioning that this is the first 
study that investigated the antioxidants, antimicrobial and safety of the flavonoid fraction of $M$. heterophylla

\section{CONCLUSIONS}

The Flavonoid fraction of $M$. heterophylla is relatively non-toxic on acute and chronic exposures at 50-100 $\mathrm{mg} / \mathrm{kg}$ of the experimental rats with the potential to serve as a candidate for the development of antimicrobial and antioxidant drug.

\section{ACKNOWLEDGEMENTS}

The authors would like to appreciate Mallam Shuaib Ma'aji and Mr Prince Chukwudi Ossai of the Department of Biochemistry, Federal University of Technology Minna, for their kind assistance during the laboratory experiments. This work was funded solely by the authors.

\section{CONFLICT OF INTEREST}

The authors declare no conflict of interest existed while conducting this study.

\section{REFERENCES}

1. Ali SS, Ayub A, Ali SN, et al. Antibacterial activity of methanolic extracts from some selected medicinal plants. Fuuasta Journal ofBiology. 2017;7(1):123-125.

2. WHO (World Health Organization). Infectious disease. 2016. WHO, Fact sheet No. 104

3. Behera PC, Ghosh M. Evaluation of antioxidant, antimicrobial, and antiurolithiatic potential of different solvent extracts of Aerva lanata linn flowers. Phamacognosis Magazine. 2018;14:53-57.

4. Ibrahim, AM, Lawal, B, Abubakar, et al. Antimicrobial and Free Radical Scavenging Potentials of $\mathrm{N}$-Hexane and Ethyl Acetate Fractions of Phyllanthus Fraternus. Nigeria Journal of Basic and Applied Science. 2017;25(2):06-11.

5. Lawal B, Shittu OK, Inje OF, et al. African Natural product with Potential Antioxidants and Hepatoprotectives Properties: A Review.Clinical Phytoscience. 2017;2(23):1-66

6. Panche, AN, Diwan, AD, and Chandra SR. Flavonoids: an overview. Journal of Nutritional Science. 2016;5:e47. Doi:10.1017/jns.2016.41

7. Yusuf AW, Lawal B, YusufMA, et al. Free Radical Scavenging, Antimicrobial Activities and Effect of SubAcute Exposure to Nigerian Xylopia aethiopica Seed extract on Liver and Kidney Functional Indices of Albino Rat. Iranian Journal of Toxicology. 2018;12(3):51-58

8. Bashir L, Shittu OK, Sani S, et al. African Natural Products with Potential Antitrypanosoma Properties: A Review. International Journal of Biochemistry Research and Review. 2015;7(2):45-79.

9. Lawal B, Shittu OK, Kabiru AY, et al. Potential antimalarials from African natural products: A review. Journal of Intercultural Ethnopharmacology. 2015;4(4):318-343

10. Zhang YY, Zhang $\mathrm{F}$, Thakur $\mathrm{K}$, et al. Effect of natural polyphenol on the oxidative stability of pecan oil. Food
Chemistry and Toxicology. 2017. Doi:10.1016/j.fct.2017.10.001

11. Toiu A, Mocan A, Vlase L, et al. Phytochemical Composition, Antioxidant, Antimicrobial and in Vivo Anti-inflammatory Activity of Traditionally Used Romanian Ajuga laxmannii (Murray) Benth. Frontiers in Pharmacology. 2018;9(7):1-16.

12. Ferrante, C, Recinella, L, Locatelli, M, et al. Protective effects induced by microwave-assisted aqueous harpagophytum extract on rat cortex synaptosomes challenged with amyloid b-peptide. Phytotherapy Research. 2017;31:1257-1264.

13. da Silva G, Serrano R, Silva O. Maytenus heterophylla and Maytenus senegalensis, two traditional herbal medicines. Journal of Natural Science and Biological Medicine. 2011;2:59-65.

14. Khalid SA, Friedrichsen GM, Christensen SB, et al. Isolation and characterization of pristimerin as the antiplasmodial and antileishmanial agent of Maytenus senegalensis (Lam.) Exell. ARKIVOC. 2007;9:129-134.

15. Muregi FW, Ishih A, Suzuki T, et al. In vivo antimalarial activity of aqueous extracts from Kenyan medicinal plants and their chloroquine (CQ) potentiation effects against a blood-induced CQ-resistant rodent parasite in mice. Phytotherapy Research. 2007;21:337-343.

16. da Silva G, Tanica $\mathrm{M}$, Rocha J, et al. In vivo antiinflammatory effect and toxicological screening of Maytenus heterophylla and Maytenus senegalensis extracts. Human and Experimental Toxicology. 2010;30(7):693-700.

17. Lindsey KL, Budesinsky M, Kohout L, et al. Antibacterial activity of maytenoic acid isolated from the root-bark of Maytenus senegalensis. South Africa Journal of Botany. 2006;72:473-477.

18. Orabi KY, Al-Qasoumi SI, El-Olemy MM, et al. Dihydroagarofuran alkaloid and triterpenes from Maytenus heterophylla and Maytenus arbutifolia. Phytochemistry. 2001;58:475-480.

19. Tsado NA, Lawal B, Ossa PC, et al. Antioxidants and Antimicrobial Activities of Methanol Extract of Newbouldialaevis and Cratevaadansonii. Journal of Pharmacy and Allied Health Sciences. 2016. Doi:10.3923/jpahs.2016

20. Eloff JNA. Sensitive and quick microplate method to determine the minimal inhibitory concentration of plant extracts for bacteria. Planta Medica.1998;64:711-713.

21. Blois MS. Antioxidant determinations by the use of a stable free radical. Nature. 1958;181:1199-1200.

22. Oyaizu, M. Studies on products of browning reactionantioxidative activities of products of browning reaction prepared from glucosamine. Journal of Nutrition. 1986;44:307-315.

23. Shittu OK, Lawal B, Blessing Uchenna AB, et al. Alteration in Biochemical Indices Following Chronic Administration of Methanolic Extract of Nigeria Bee Propolis in Wister Rats. Asian Pacific Journal of Tropical Diseases. 2015;5(8):654-657.

24. Lawal B, Shittu OK. Oibiokpa IF, et al. Antimicrobial evaluation, acute and sub-acute toxicity studies of Allium sativum. Journal of Acute Diseases. 2016;5(4):296-301. 
25. Tietz NW. Clinical guide to laboratory tests. 3rd ed. Philadelphia, PA: WB Saunders Company; 1995, p. 286288.

26. Reitman S, Frankel S. A colorimetric method for the determination of serum glutamic oxalacetic and glutamic pyruvic transaminases. American Journal of Clinical Pathology. 1957;28:56-63.

27. Gornall AC, Bardawill CJ, David MM. Determination of serum protein by means of biuret reaction. Journal of Biology and Chemistry. 1949;177:751-766.

28. Doumas BT, Watson WA, Biggs HG. Albumin standards and the measurement of serum album with bromocresol green. Clinical Chemistry Acta. 1971;31:87-96.

29. Blass KG, Thierbert RJ, Lam LK. A study of the mechanism of the Jaff'e reaction. Z Klin Chem Klin Biochemistry. 1974;12:336-343.

30. Ahmed AS, McGaw LJ, Eloff JN. Evaluation of pharmacological activities, cytotoxicity and phenolic composition of four Maytenus species used in southern African traditional medicine to treat intestinal infections and diarrhoeal diseases. BMC Complementary and Alternative Medicine. 2013;13:100-110.
31. Kuete V, Efferth T. Cameroonian medicinal plants: Pharmacology and derived natural products. Frontiers in Pharmacology. 2010;25(1):123 Doi:10.3389/fphar.2010.00123.

32. Al-Enazi NM, Awaad AS, Zain ME, et al. Antimicrobial, antioxidant and anticancer activities of Laurencia catarinensis, Laurencia majuscula and Padina pavonica extracts. Saudi Pharmaceutical Journal. 2018;26:44-52.

33. Wei L, Zhang W, Yin L, et al. Extraction optimization of total triterpenoids from Jatropha curcas leaves using response surface methodology and evaluations of their antimicrobial and antioxidant capacities. Electron Journal of Biotechnology. 2015;18:88-95.

34. Shittu OK, Lawal B, Abubakar NA, et al. Toxicological Implications of Methanol Extract from Nigerian Bee Propolis on Some Selected Rat Tissues. Journal of Pharmaceutical and Biomedical Science. 2015;05(06):499-506.

35. Bashir L, Shittu OK, Busari MB, et al. Safety evaluation of giant African land snails (Archachatina maginata) haemolymph on hematological and biochemical parameters of Albino rats. Journal of Advance Medical and Pharmaceutical Sciences. 2015;3(3):122-130. 